\title{
Finnish Guidelines of Ventilation Rates for Non-residential Buildings
}

\author{
Olli Seppänen ${ }^{1}$, Jorma Säteri², and Mervi $\mathrm{Ahola}^{3 *}$ \\ ${ }^{1}$ The Finnish Association of HVAC Societies FINVAC ry \\ ${ }^{2}$ Metropolia University of Applied Sciences \\ ${ }^{3}$ Finnish Society of Indoor Air Quality and Climate, FISIAQ
}

\begin{abstract}
The new Finnish Decree on the Indoor Climate and Ventilation of New Buildings 1009/2017 [1] is part of the implementation of Energy Performance of Buildings Directive in the EU. The new Decree specifies the minimum design ventilation rate to be $6 \mathrm{dm}^{3} / \mathrm{s}$, person (outdoor air). The Decree also specifies that the ventilation shall be controlled by demand when feasible. These requirements in the Decree were considered to be too plain and inadequate for practical design. FINVAC carried out an investigation [2,3] regarding the experience on the old ventilation regulation [4]. Based on the result of these investigations new guidelines were prepared and published in 2018. Majority of the experts considered $6 \mathrm{dm}^{3} / \mathrm{s}$, person as an appropriate value of the minimum ventilation rate. The investigations revealed that in many cases the old recommended values $\left(\mathrm{dm}^{3} / \mathrm{s}, \mathrm{m}^{2}\right)$ were either too high or too low. This has led to poor air quality in some cases and excess energy use in some cases. Too high ventilation rates were used for corridors, restaurants, cafeterias, supermarkets, department stores, shops, hotel rooms, auditoriums, halls, and washing rooms. The total air flow was also too high for day care centres, and for some apartments. Too low ventilation rates were given for elderly homes, classrooms, fitness centres, sports halls, residential kitchen hoods, operation rooms in hospitals, and for some apartments. Detailed guidelines were prepared and structured by building type (offices, schools, hospitals, elderly homes, restaurants, hotels, stores, sports facilities, barracks, theatres, industrial working places, kitchens, spaces for personal hygiene and technical rooms). Separate guidelines were prepared for residential buildings [5]. Both guidelines were published in the beginning of the year 2018.
\end{abstract}

\section{Background}

Implementation of EU directives [6,7] has forced EU member countries to revise the building regulations related energy efficiency.

In Finland Ministry of the Environment (in charge of building regulations) invited FINVAC, Federation of Finnish HVAC Associations, to revise the old guideline [4] values of ventilation rates as part of the nearly zero energy building regulations and guidelines.

The revised ventilation guidelines presented in this paper are part of this process. The values are optimized for energy efficiency and indoor air quality.

\section{Methods}

The revision of the guidelines was based mainly on the experience from practice. Several methods were used in the study to collect information: an expert panel, questionnaires to experts in two stages, interviews of selected experts, open workshops, and analysis of results in the light of the existing building code, and also acknowledging the work done in the working groups of CEN TC 156 [8]. The participants of the study were selected from the members of FINVAC, representing various professions in construction process.

An expert panel was established for the study, a questionnaire was sent to selected ventilation experts of FINVAC in two stages, the first focusing on general questions and the second on ventilation rates in old building code. Two open seminars were organized for professionals. Seminars were monitored and results analysed. Interviews of selected experts were focusing on specific technical questions.

\section{Results}

Several conclusions were drawn from the collected data and changes made accordingly in the new guidelines.

1) Guideline values for ventilation cannot be based only on ventilation rate per person but other values like $\mathrm{dm}^{3} / \mathrm{s}, \mathrm{m}^{2}$ are needed as well.

2) Based on practical experience the ventilation rates for many spaces can be reduced without deteriorating the indoor air quality.

3) Some spaces need more ventilation but much fewer than those having too high ventilation rates

\footnotetext{
* Corresponding author: mervi.ahola@sisailmayhdistys.fi
} 
4) As the number of occupants vary in many spaces, ventilation must be controlled based on the number occupants or air quality in large spaces with significantly varying occupancy.

5)As the pollution loads and use of spaces change over the time the ventilation rates should be adjusted to this change.

Numeric values of the new guidelines are presented in the following by building type with some justification and guidelines.

In addition to buildings and rooms types presented below the new guidelines include barracks, theatres and other public spaces, sports halls, industrial working places, commercial kitchens, spaces for personal hygiene and technical rooms.

\subsection{Office buildings}

Actual use of the space and the floor area per occupant varies depending on the building type. The building may not have any more specific offices or permanent working stations, but the use of the space is flexible, and the workers may move from place to place during the day and depending the task they are performing. Specific corridors or rest areas may not exist anymore. For these reasons the ventilation must be designed based on the total number of workers in the specific floor, area or zone. The total ventilation rate should not be below 1 $\mathrm{dm}^{3} / \mathrm{s}, \mathrm{m}^{2}$. However, often the ventilation rates are higher than minimum to improve productivity and air quality. Also, higher ventilation rates are needed to control the thermal environment. The ventilation must be controlled by demand if the total ventilation rate for a zone or space is greater than $100 \mathrm{dm}^{3} / \mathrm{s}, \mathrm{m}^{2}$ and the number of occupants has a large variation like in conference rooms designed for more than 10 occupants. When the demand-controlled ventilation is used the minimum ventilation rate in all areas must be higher than $30 \%$ of the design value, and higher than $0,35 \mathrm{dm}^{3} / \mathrm{s}, \mathrm{m}^{2}$. Corridors can be ventilated, at least partly, with transfer air from the office areas.

Table 1. Guideline values for office buildings.

\begin{tabular}{|c|c|c|}
\hline \multirow{2}{*}{ Room type } & \multicolumn{2}{|c|}{ Outdoor air flow } \\
\hline & $\mathrm{dm}^{3} / \mathrm{s}$, person & $\mathrm{dm}^{3} / \mathrm{s}, \mathrm{m}^{2}$ \\
\hline Office room $^{1}$ & 6 & 1 \\
\hline Open plan office $^{1}$ & 6 & 1,5 \\
\hline $\begin{array}{c}\text { Meeting or conference } \\
\text { room }^{1,2}\end{array}$ & 6 & 3 \\
\hline $\begin{array}{c}\text { Corridor }^{3} \text { (not for long } \\
\text { term occupancy) }^{\text {Ond }}\end{array}$ & & 0,5 \\
\hline
\end{tabular}

${ }^{1}$ Criteria leading to higher ventilation to be used in design ${ }^{2}$ Demand controlled ventilation if room for more than 10 occupants

${ }^{3}$ Ventilation with transfer air from office areas

\subsection{Schools and Day care centres}

Design of ventilation for schools must be based on the type of education offered in the school building. The spaces in schools are more and more for multipurpose use with varying occupancy loads. The ventilation design of school can be based on the assumption that all spaces are not used simultaneously with maximum occupancy, however, it is important to design the ventilation so that total ventilation rate of the whole school building is based of the total number of people in the building (students, teachers and personnel). Ventilation air flow must be directed to the areas/spaces in use, however, the minimum ventilation in all spaces is $0,35 \mathrm{dm}^{3} / \mathrm{s}, \mathrm{m}^{2}$. Ventilation must be adapted also to the use of the school building out of the normal school hours. Design ventilation rate for school buildings is 6 $\mathrm{dm}^{3} / \mathrm{s}$, person. This is justified for adults and children due to higher activity level and higher metabolic rate of children. Higher ventilation rates than $6 \mathrm{dm}^{3} / \mathrm{s}$, person is needed for spaces with higher activity like halls for gymnastics and sports as well as classrooms with higher pollution generation such as home economics, metal works, wood works etc.

Two alternative ways for design of ventilation can be used 1) design the whole school building as a whole and use total ventilation rate $6 \mathrm{dm}^{3} / \mathrm{s}$, person for the design occupancy of the school 2) design the ventilation for each space based on the guideline values in the table 2 .

Table 2. Guideline values for school buildings

\begin{tabular}{|c|c|c|}
\hline \multirow[t]{2}{*}{ Room type } & \multicolumn{2}{|c|}{ Outdoor air flow } \\
\hline & $\mathrm{dm}^{3} / \mathrm{s}$, person & $\mathrm{dm}^{3} / \mathrm{s}, \mathrm{m}^{2}$ \\
\hline School building & 6 & \\
\hline $\begin{array}{l}\text { Class rooms and } \\
\text { workshop rooms }\end{array}$ & 6 & 3 \\
\hline Rooms for teachers & & 2 \\
\hline Corridors and lobbies & & 3 \\
\hline $\begin{array}{l}\text { Corridors, not for longer } \\
\text { term occupancy }\end{array}$ & & 1 \\
\hline $\begin{array}{l}\text { Large halls } \mathrm{s}^{1,2} \text { (sports hall), } \\
\text { in sports activity }\end{array}$ & & 2 \\
\hline $\begin{array}{l}\text { Large halls }{ }^{1,2} \text { (sports hall), } \\
\text { in assembly use }\end{array}$ & 6 & \\
\hline Sports hall / auditorium ${ }^{3}$ & 6 & \\
\hline Lecture halls ${ }^{3}$ & 6 & \\
\hline Libraries, offices & & 2 \\
\hline Lunch areas ${ }^{4}$ & 6 & 3 \\
\hline $\begin{array}{l}\text { Day care centres and } \\
\text { preschools }^{5}\end{array}$ & 6 & 3 \\
\hline
\end{tabular}

${ }^{1}$ Criteria leading to higher ventilation to be used in design

${ }^{2}$ Ventilation must be adjustable to the use of the hall.

${ }^{3}$ Design and control of ventilation based on the size of the audience (seats)

${ }^{4}$ Lunch areas are often used also for teaching

${ }^{5}$ All rooms may not be used simultaneously 


\subsection{Hospitals and medical centres}

Basic criteria for ventilation in hospital wards, and rooms in medical centres etc. should be based on the number of occupants in the room taking at the same time into a account the specific pollutant load in in the room. Due to the higher pollution generation and need for good air quality, the basic air flow in medical building is 10 $\mathrm{dm}^{3} / \mathrm{s}$, person. Pollution load is assumed to be proportional to the occupancy. Operation theatres and treatment room where the ventilation is design based on the other criteria than number of occupants are excluded from these guidelines. In the patient rooms the ventilation is designed based on the number of beds and the need for ventilation for bathroom connected to the patient room so that the supply and the exhaust air flows are in balance.

Table 3. Guideline values for school buildings

\begin{tabular}{|c|c|c|}
\hline \multirow[t]{2}{*}{ Room type } & \multicolumn{2}{|c|}{ Outdoor air flow } \\
\hline & $\mathrm{dm}^{3} / \mathrm{s}$ & $\mathrm{dm}^{3} / \mathrm{s}, \mathrm{m}^{2}$ \\
\hline Patient room ${ }^{1}$ & 10/bed & 2,5 \\
\hline $\begin{array}{l}\text { Patient room with } \\
\text { bathroom } \\
\text { Exhaust air flow } \\
\text { minimum } \\
30 \mathrm{dm}^{3} / \mathrm{s} \text {, room } \\
\end{array}$ & $\begin{array}{l}\text { Equal to the } \\
\text { exhaust air } \\
\text { flow but with } \\
\text { minimum of } \\
10 / \mathrm{bed}\end{array}$ & $\begin{array}{c}\text { Equal to the } \\
\text { exhaust air } \\
\text { flow but with } \\
\text { minimum of } \\
2,5 \\
\end{array}$ \\
\hline $\begin{array}{c}\text { Doctors reception } \\
\text { room }^{1} \\
\end{array}$ & 20/room & 2 \\
\hline $\begin{array}{l}\text { Room for investigations } \\
\text { and medical treatment }{ }^{1}\end{array}$ & 25/room & 2 \\
\hline Laboratory $^{1}$ & & 4 \\
\hline Waiting areas $^{2}$ & & 3 \\
\hline Corridors & & 1 \\
\hline Dining areas & 3 & 3 \\
\hline Storages & \multicolumn{2}{|c|}{ Exhaust air flow $0,5 \mathrm{dm}^{3} / \mathrm{s}, \mathrm{m}^{2}$} \\
\hline
\end{tabular}

${ }^{1}$ Exhaust air flow must be equal to the outdoor air flow.

${ }^{2}$ Also the corridors if used for waiting.

\subsection{Restaurants}

Ventilation of restaurants depend on the type of the food services. Ventilation must be designed based on the use of the restaurant and the total number of customers. If the number of tables and chairs is not known, the ventilation can be designed based on the floor area. The ventilation of restaurant kitchens must be designed based on the type of kitchen and the number and type of the kitchen equipment. During the life time of the space intended for restaurant activities the type of restaurant may change several times. For that reason, it is advisable to design the ventilation ducts for minimum of $6 \mathrm{dm}^{3} / \mathrm{s}$, $\mathrm{m}^{2}$ even though the first user would not need so much ventilation. If the restaurant has more than 30 places for customers, the ventilation must be controlled by the use and the number of occupants.
Table 4. Guideline values for restaurants. The criteria leading to higher ventilation to be used in design.

\begin{tabular}{|c|c|c|}
\hline Room type & \multicolumn{2}{|c|}{ Outdoor air flow } \\
\hline $\begin{array}{c}\text { Lunch restaurant, work } \\
\text { place cafeterias }\end{array}$ & 6 & $\mathrm{dm}^{3} / \mathrm{s}, \mathrm{s}, \mathrm{m}^{2}$ \\
\hline $\begin{array}{c}\text { Pizzeria, fast food } \\
\text { restaurants }\end{array}$ & 6 & 3 \\
\hline Dining restaurants & 6 & 6 \\
\hline Night clubs & 6 & 6 \\
\hline $\begin{array}{c}\text { Eating area in assisted } \\
\text { housing etc }\end{array}$ & 6 & 3 \\
\hline Coffee shops, bars & 6 & 3 \\
\hline
\end{tabular}

\subsection{Elderly homes and assisted housing}

Several levels for assisted housing and elderly homes are in the market. Design of ventilation depends on the condition of the occupants. Ventilation for housing for occupants in good condition can be designed as normal apartments and assisted housing with occupants in poor condition can be designed more like hospitals. Often the floor area per occupant is smaller in assisted housing than in normal housing and the pollutant load is higher due to various reasons. For those reasons the basic design ventilation rate is $10 \mathrm{dm}^{3} / \mathrm{s}$, person

Table 5. Guideline values for elderly homes and assisted housing

\begin{tabular}{|c|c|c|}
\hline Room type & Outdoor air flow & Exhaust air flow \\
\hline $\begin{array}{l}\text { Assisted housing } \\
\text { with own kitchen } \\
\text { and bathroom }{ }^{1}\end{array}$ & $\begin{array}{c}15 \mathrm{dm}^{3} / \mathrm{s} \text {, unit } \\
\text { (dwelling of one } \\
\text { person) } \\
25 \mathrm{dm}^{3} / \mathrm{s} \text {, unit (for } \\
\text { double occupancy) }\end{array}$ & $\begin{array}{c}\text { Bathroom: } \\
15 \mathrm{dm}^{3} / \mathrm{s} \\
\text { Toilet } 10 \mathrm{dm}^{3} / \mathrm{s} \\
\text { (if detached) } \\
\text { Kitchen range } \\
10 \mathrm{dm}^{3} / \mathrm{s}\end{array}$ \\
\hline $\begin{array}{l}\text { Assisted housing } \\
\text { without kitchen }\end{array}$ & $\begin{array}{c}15 \mathrm{dm}^{3} / \mathrm{s} \text {, unit } \\
\text { (dwelling of one } \\
\text { person) } \\
20 \mathrm{dm}^{3} / \mathrm{s} \text {, unit (for } \\
\text { double occupancy) }\end{array}$ & $\begin{array}{c}\text { Equal to the } \\
\text { outdoor air flow }\end{array}$ \\
\hline $\begin{array}{l}\text { Common areas } \\
\text { (dining, TV-room } \\
\text { etc) }\end{array}$ & $3 \mathrm{dm}^{3} / \mathrm{s}, \mathrm{m}^{2}$ & $3 \mathrm{dm}^{3} / \mathrm{s}, \mathrm{m}^{2}$ \\
\hline Corridors & $0,5 \mathrm{dm}^{3} / \mathrm{s}, \mathrm{m}^{2}$ & \\
\hline $\begin{array}{l}\text { Coffee room for } \\
\text { personnel }\end{array}$ & $3 \mathrm{dm}^{3} / \mathrm{s}, \mathrm{m}^{2}$ & \\
\hline $\begin{array}{l}\text { Storage (clean } \\
\text { clothes) }\end{array}$ & & $1 \mathrm{dm}^{3} / \mathrm{s}, \mathrm{m}^{2}$ \\
\hline $\begin{array}{l}\text { Storage (used } \\
\text { clothes) }\end{array}$ & & $3 \mathrm{dm}^{3} / \mathrm{s}, \mathrm{m}^{2}$ \\
\hline
\end{tabular}

${ }^{1}$ Criteria leading to higher ventilation must be used in design. Exhaust air flow rate must be equal to the outdoor air flow rate.

\subsection{Stores}

Pollution and olfactory load, number of customers and floor area of the store must be taken into account in design of ventilation for stores. Ventilation of small store shall be designed based on the floor area and pollution load generated from the goods in the store. Number of customers should be included in the design criteria of 
large stores. Ventilation in large stores must be controllable by the number of customers in the store.

Table 6. Guideline values for stores.

\begin{tabular}{|c|c|c|}
\hline Room type & \multicolumn{2}{|c|}{ Outdoor air flow } \\
\hline & $\begin{array}{c}\mathrm{dm}^{3} / \mathrm{s}, \\
\text { person }\end{array}$ & $\begin{array}{c}\mathrm{dm}^{3} / \mathrm{s}, \\
\mathrm{m}^{2}\end{array}$ \\
\hline $\begin{array}{c}\text { Small stores, low pollution load } \\
\text { (Clothing etc) }\end{array}$ & 1,5 \\
\hline $\begin{array}{c}\text { Small stores, average pollution load } \\
\text { (Grocery stores, bookstores, hair } \\
\text { dresser) }\end{array}$ & 2 \\
\hline $\begin{array}{c}\text { Small stores, heavy pollution load } \\
\text { (Cosmetics, pets, florist) }\end{array}$ & 3 \\
\hline $\begin{array}{c}\text { Large stores }{ }^{1} \text { over } 400 \mathrm{~m}^{2}, \\
\text { (Super market etc) }\end{array}$ & 6 & 1 \\
\hline \multicolumn{2}{|c|}{ Storages ${ }^{2}$} & $0,35-$ \\
\hline $\begin{array}{l}{ }^{1} \text { Design } 6 \mathrm{dm}^{3} / \mathrm{s}, \text { person or } 1 \mathrm{dm}^{3} / \mathrm{s}, \mathrm{m}^{2}, \\
\mathrm{dm}^{3} / \mathrm{s}, \mathrm{m}^{2}\end{array}$ \\
${ }^{2}$ wependith minimum of 0,5 \\
\hline on the type of stored goods
\end{tabular}

\section{Discussion}

In the design stage the number of occupants for a specific space is often not known. In this case the design must be based on some other criteria. However, in the design stage the intended use of the space and floor area are always available and can easily be used in the design. New guideline gives values for various spaces based on the use and floor area of the use of the space if number of occupants is not known. These tabled guideline values are an important tool for a designer and are commonly followed. They are important in maintaining good indoor air quality without using excess energy.

The basic ventilation rate $6 \mathrm{dm}^{3} / \mathrm{s}$, person has been used as the basic ventilation rate since 2012 in Finland [4]. The experience from practice shows that it is an appropriate value as a minimum ventilation rate. The CEN standards $[9,10]$ suggests for design ventilation rate 10,7 , or $4 \mathrm{dm}^{3} / \mathrm{s}$, person in categories I, II and III. Finnish minimum is between cat II and III. The CEN standard [9] also suggests to add ventilation due to emissions from building materials. This approach was not considered to be practical in Finland as the emissions are not yet know at design stage. In Finland there has been the emission control system of building materials since 1995 [11]. This procedure has reduced the emissions and need for ventilation. Presently more than 4500 building materials, furnish and ventilation components have been tested for emissions and labelled for low emission (M1). It was considered more feasible to specify the ventilation rates by building and room type which is always know at design stage.

When comparing the European code and guideline values of ventilation Finnish new guideline values seem to be close to the average. The Health Vent study [12] showed that in a $12 \mathrm{~m}^{2}$ office room the range in EU countries was $6-25 \mathrm{dm}^{3} / \mathrm{s}$, and in the Finnish guideline $12 \mathrm{dm}^{3} / \mathrm{s}$, in a $50 \mathrm{~m}^{2}$ classroom the range in EU countries was $104-250 \mathrm{dm}^{3} / \mathrm{s}$, and in the Finnish guideline 150 $\mathrm{dm}^{3} / \mathrm{s}$, in a $50 \mathrm{~m}^{2}$ playroom of a day care centre the range in EU countries was $100-290 \mathrm{dm}^{3} / \mathrm{s}$, and in the Finnish guideline $150 \mathrm{dm}^{3} / \mathrm{s}$.

The Finnish new guidelines for ventilation rates are also in the line with international survey on ventilation and health study regarding the minimum ventilation rates [13].

\section{References}

1. Decree of the Ministry of the Environment on the Indoor Climate and Ventilation of New Buildings $1009 / 2017$.

2. Seppänen, Olli, Railio Jorma. 2014. D2uusintatarveselvitys - in Finnish (Study on the need for revisions of Finnish Building Code Part D2). The HVAC Association of Finland (SuLVI) and The Finnish Ministry of the Environment.

3. Olli Seppänen Olli, Railio Jorma, Strand Tiina 2016. Finnish Ventilation Regulations for Better IAQ and Energy Efficiency, AIVC Annual Confrernce 2015.

4. National building code of Finland. Part D2 (2012). Indoor air quality and ventilation. Ministry of the Environment, Finland.

5. J. Säteri, O. Seppänen, M. Ahola. Finnish design ventilation rates for residential buildings (in these proceedings)

6. Directive 2002/91/EC of the European Parliament and of the Council on the energy performance of buildings

7. Directive 2010/31/EU of the European Parliament and of the Council on the energy performance of buildings

8. European Committee for Standardization. Technical Committee Ventialtion for Buildings.

9. EN 16798-1:2018 Energy performance of buildings. Indoor environmental input parameters for design and assessment of energy performance of buildings addressing indoor air quality, thermal environment, lighting and acoustics.

10. EN 16798-2.Technical report. Guideline for using indoor environmental input parameters for the design and assessment of energy performance of buildings.

11. Finnish Society of Indoor Air Quality and Climate. Classification of Indoor Environment 2018, Target Values, Design Guidance, and Product Requirements 2018.

12. Seppänen Olli, Final Report, Work Package 5, Healthvent project, Health-based ventilation guidelines for Euroope. EU Contract No.: 200912 08Federation of European Heating, Ventilation and Air-conditioning Associations, 2012.

13. Carrera Paolo,Wargocki Pawel, Fanettia Annaclara et al. What does the scientific literature tell us about the ventilation-health relationship in public and residential buildings? Building and Environment,Volume 94, Part 1, December 2015, Pages 273-286 